\title{
INTELLECTUAL CAPITAL PENGARUHNYA TERHADAP RETURN ON ASSETS (ROA) PADA PERUSAHAAN SUB SEKTOR OTOMOTIF DAN KOMPONEN DI BURSA EFEK INDONESIA
}

\author{
Cening Ayuni Ratnadi ${ }^{1}$ Gusti Ayu Mahanavami ${ }^{2 *}$ Ida Bagus Ngurah Wimpascima ${ }^{3}$ \\ 123 STIMI Handayani, Denpasar, Bali-Indonesia \\ *gustiayumahanavami@gmail.com
}

\begin{abstract}
Improvements and changes in the business sector make the company believe that intellectual capital is an important component and asset in measuring and evaluating performance among business sectors. This study aims to examine the effect of Intellectual Capital components, namely Value Added Capital Employed (VACA), Value Added Human Capital (VAHU) and Structural Capital Value added (STVA) on Return On Assets (ROA) in automotive sub-sector companies and components on the Stock Exchange. Indonesia. The sampling technique used purposive sampling with a total sample of 5 companies in the automotive and component sub-sector. The data used are financial statements for the period 2015 - 2019 published on the company's official website. The results showed that Value Added Capital Employed (VACA) had a significant positive effect on Return On Assets (ROA) in Automotive and Component Sub-Sector Companies, Value Added Human Capital (VAHU) had a negative and insignificant effect on Return On Assets (ROA). Automotive and Component Sub-Sector Companies and Structural Capital Value Added (STVA) have a positive but not significant effect on Return On Assets (ROA) in Automotive and Component Sub-Sector Companies.
\end{abstract}

Keywords: Value Added Capital Employed (VACA), Value Added Human Capital (VAHU), Structural Capital Value Added (STVA) and Return On Assets (ROA).

\begin{abstract}
Abstrak
Perbaikan dan perubahan di bidang bisnis menjadikan perusahaan percaya bahwa modal intelektual menjadi komponen dan aset penting dalam mengukur dan mengevaluasi kinerja di antara sektor bisnis. Penelitian ini bertujuan untuk menguji pengaruh komponen Intellectual Capital yaitu Value Added Capital Employed (VACA), Value Added Human Capital (VAHU) dan Structural Capital Value added (STVA) terhadap Return On Assets (ROA) pada perusahaan sub sektor otomotif dan komponen di Bursa Efek Indonesia. Teknik pengambilan sampel menggunakan purposive sampling dengan jumlah sampel sebanyak 5 perusahaan sub sektor otomotif dan komponen. Data yang digunakan adalah laporan keuangan periode tahun 2015 - 2019 yang dipublikasikan di website resmi perusahaan. Hasil penelitian menunjukkan bahwa Value Added Capital Employed (VACA) berpengaruh positif siginifikan terhadap Return On Assets (ROA) Pada Perusahaan Sub Sektor Otomotif Dan Komponen, Value Added Human Capital (VAHU) mempunyai pengaruh negatif dan tidak signifikan terhadap Return On Assets (ROA) Pada Perusahaan Sub Sektor Otomotif Dan Komponen dan Structural Capital Value Added (STVA) berpengaruh positif namun tidak signifikan terhadap Return On Assets (ROA) Pada Perusahaan Sub Sektor Otomotif Dan Komponen.
\end{abstract}

Kata Kunci: Value Added Capital Employed (VACA), Value Added Human Capital (VAHU), Structural Capital Value Added (STVA) dan Return On Assets (ROA)

\section{PENDAHULUAN}

Dampak dari knowledge sebagai aset potensial bagi perusahaan dalam meningkatkan nilai perusahaan, identifikasi dan pengelolaan dalam bentuk intangible assets (aset tak berwujud) atau biasa disebut intellectual capital semakin penting untuk eksistensi dari suatu bisnis. Modal intelektual yang terdiri dari customer capital, human capital, dan structural capital merupakan pendorong utama dari inovasi dan keunggulan kompetitif dalam ekonomi berbasis pengetahuan yang telah berkembang. Saat yang sama, manajemen pengetahuan (knowledge manajement) diakui sebagai aktivitas dasar untuk memperoleh, menumbuhkan, dan mempertahankan intellectual capital dalam organisasi (Fajariyah, 2012). Artinya bahwa keberhasilan pengelolaan intellectual capital sangat berkaitan dengan proses knowledge manajement organisasi, yang selanjutnya menyiratkan keberhasilan implementasi dan penggunaan knowledge manajement dalam menjamin perolehan dan pertumbuhan intellectual capital. 
Intellectual Capital suatu perusahaan dapat diukur dengan metode $\mathrm{VAIC}^{\mathrm{TM}}$ (Value Added Intellectual Coefficient) (Pulic, 1998 dalam Devi et al., 2017). Metode VAIC ${ }^{\mathrm{TM}}$ merupakan koefisien nilai tambah yang terdiri dari tiga komponen pembentuk intellectual capital, yaitu Capital Employed Efficiency atau yang kerap disebut Value Added Capital Employee (VACA), Human Capital Efficiency yang juga sering disebut Value Added Human Capital (VAHU), dan Structural Capital Efficiency atau disebut juga dengan Structural Capital Value Added (STVA). VAIC ${ }^{\mathrm{TM}}$ menggambarkan seberapa besar intellectual capital menambah nilai suatu perusahaan dari penggunaan aset tersebut.

Keberadaan industri otomotif Indonesia menunjukkan eksistensi dan pertumbuhan positif. Potensi yang cukup signifikan ditunjukkan dengan tingginya permintaan akan kendaraan bermotor, khususnya kendaraan roda empat. Berdasarkan data yang dirilis oleh Gabungan Industri Kendaraan Bermotor Indonesia (Gaikindo), penjualan mobil di tahun 2017 terlihat meningkat jika dibandingkan dengan tahun 2016. Pada triwulan pertama saja, penjualan meningkat lebih dari 8 persen jika dibanding dengan periode yang sama di tahun 2016. Indonesia telah berkembang sebagai salah satu negara basis produksi otomotif dunia. Akan tetapi, di masa depan persaingan antar produsen di industri otomotif akan semakin menantang. Persaingan tidak hanya terjadi antar produsen di pasar domestik saja, namun juga di pasar otomotif regional dan global. Oleh karena itu, agar dapat terus berkembang, industri otomotif nasional perlu meningkatkan inovasi dan daya saingnya. (Kompas.com 2017).

Saat ini Intellectual Capital atau modal intelektual menjadi salah satu isu penting yang sangat menarik untuk dikaji terbukti dari banyaknya penelitian tentang Intellectual Capital yang dilakukan, diantaranya terdapat penelitian (Endri, 2020) yang melakukan penelitian pada perusahaan Shari'ah Commercial Bank di Indonesia menunjukkan hasil bahwa Value Added Capital Employed (VACA) mempunyai pengaruh negatif signifikan terhadap Financial Performance (Return On Assets), lalu Value Added Human Capital (VAHU) dan Structural Capital Value Added (STVA) mempunyai pengaruh positif signifikan terhadap Financial Performance (Return On Asset). Penelitian yang dilakukan oleh (Okenwa Cy, O., Ndubuisi, A. N., \& Chidoziem, 2017) di Nigeria menunjukkan hasil bahwa komponen intellectual capital yakni Capital Employed Efficiency (CEE), Human Capital Efficiency (HCE) dan Structural Capital Efficiency (SCE) memiliki pengaruh positif dan signifikan terhadap Financial Performance yang diproksikan dengan Return On Assets (ROA).

Penelitian (Kazhimy \& Sulasmiyati, 2019) pada perusahaan properti dan real estate yang terdaftar di Bursa Efek Indonesia hasilnya membuktikan bahwa Value Added Capital Employed (VACA), Value Added Human Capital (VAHU) dan Structural Capital Value Added (STVA) mempunyai pengaruh positif signifikan terhadap kinerja keuangan perusahaan yang diproksikan dengan return on assets. Perbedaan hasil penelitian yang dilakukan (Smriti \& Das, 2017) pada perusahaan Farmasi dan Obat-obatan di Bombay Stock Exchange India mengungkapkan bahwa Intellectual Capital memiliki pengaruh negatif dan tidak signifikan atau dengan kata lain tidak memiliki pengaruh terhadap kinerja keuangan (return on assets). Hasil lainnya juga ditunjukkan pada penelitian (Ozkan et al., 2017) yang meneliti di Bank Operasi Turki membuktikan bahwa Capital Employed Efficiency (CEE) dan Human Capital Efficiency (HCE) berpengaruh positif dan signifikan terhadap Return On Assets (ROA) sedangkan Structural Capital Efficiency (SCE) memiliki pengaruh negatif tidak signifikan terhadap Return On Assets (ROA). (Marbun \& Saragih, 2018) melakukan penelitian pada perusahaan perbankan yang terdaftar di Bursa Efek Indonesia serta penelitian dari (Naufallita \& Hendratmi, 2019) pada perusahaan Asuransi Syariah juga membuktikan bahwa komponen intellectual capital yaitu value added human capital (VAHU) dan structural capital value added (STVA) berpengaruh positif namun tidak signifikan atau tidak memiliki pengaruh terhadap kinerja perusahaan (return on asset) sedangkan value added capital employed (VACA) berpengaruh positif signifikan terhadap kinerja perusahaan (return on assets).

Berdasarkan beberapa penelitian yang telah dilakukan sebelumnya baik di luar negeri maupun di Indonesia menunjukkan hasil yang tidak konsisten mengenai pengaruh intellectual capital terhadap kinerja keuangan perusahaan, sehingga dilakukan penelitian kembali mengenai pengaruh intellectual capital terhadap kinerja keuangan yang diproksikan dengan Return On Assets (ROA) pada perusahaan sub sektor otomotif dan komponen yang terdaftar di Bursa Efek Indonesia. Adapun tujuan dalam penelitian ini adalah untuk mengetahui pengaruh Value Added Capital Employed (VACA), Value Added Human Capital (VAHU) dan Structural Capital Value Added (STVA) terhadap Return On Asset 


\section{TELAAH LITERATUR DAN KAJIAN PUSTAKA \\ Resource Based Theory}

Resource Based Theory menyatakan bahwa perusahaan memiliki sumber daya yang dapat menjadikan perusahaan tersebut mempunyai keunggulan bersaing dan mampu mengarahkan perusahaan untuk memiliki kinerja jangka panjang yang baik (Ulum, 2017:23). Pendekatan Resource Based Theory menyatakan perusahaan dapat mencapai keunggulan bersaing yang berkesinambungan dan memperoleh keuntungan superior dengan memiliki atau mengendalikan aset-aset strategis baik yang berwujud maupun tidak berwujud (Fajariyah, 2012). Barney dalam (Ulum, 2017:24) menyarankan untuk memahami sumber dari keunggulan bersaing berkelanjutan (sustained competitive advantages), perlu dibangun suatu model teoritis yang bermula dari sebuah asumsi sumber daya perusahaan heterogen dan immobile.

\section{Teori Stakeholder}

Menurut teori stakeholder, manajemen diharapkan melakukan aktivitas yang dianggap penting oleh stakeholder dan melaporkan kembali aktivitas-aktivitas tersebut pada stakeholder. Teori ini menyatakan bahwa seluruh stakeholder memiliki hak untuk disediakan informasi tentang bagaimana aktivitas organisasi mempengaruhi mereka (sebagai contoh melalui solusi, sponsorship, inisiatif pengamanan, dan lain-lain) bahkan ketika mereka memilih untuk tidak menggunakan informasi tersebut dan bahkan ketika mereka tidak dapat secara langsung menaikan peran yang konstruktif dalam kelangsungan hidup organisasi (Deegan, 2004 dalam Ulum, 2017:35).

Dalam konteks tentang konsep Intellectual Capital, teori stakeholder harus dipandang dari kedua bidangnya, baik bidang etika (moral) maupun bidang manajerial. Bidang etika berargumen bahwa seluruh stakeholder memiliki hak untuk diperlakukan secara adil oleh organisasi atau perusahaan dan manajer harus mengelolanya untuk keuntungan seluruh stakeholder (Ulum, 2017:36). Ketika manajer mampu mengelola organisasi atau perusahaan secara maksimal, khususnya dalam upaya penciptaan nilai bagi perusahaan, artinya manajer telah memenuhi aspek etika dari teori ini. Penciptaan nilai dalam konteks ini adalah dengan memanfaatkan seluruh potensi yang dimiliki perusahaan baik karyawan (human capital), aset fisik (physical capital) maupun structural capital sehingga dapat mendorong kinerja keuangan perusahaan untuk kepentingan stakeholder.

\section{Intellectual Capital}

Sveiby mengklasifikasikan intellectual capital ke dalam tiga area yang tidak berwujud yaitu human capital, structural capital dan capital employed. Intellectual capital mewakili sumber daya yang bernilai dan kemampuan untuk bertindak berdasarkan pada pengetahuan. Namun intellectual capital merupakan hasil akhir dari proses transformasi pengetahuan ke dalam intellectual property atau intellectual assets perusahaan (Pratama \& Achmad, 2015).

\section{Value Added Intellectual Coefficient (VAIC ${ }^{\mathrm{TM}}$ )}

Metode VAIC $^{\text {TM }}$ dikembangkan oleh Pulic yang merupakan suatu model yang mengukur intellectual capital melalui kemampuan perusahaan dalam menciptakan nilai tambah atau value added (VA) yang dihasilkan melalui Capital Employed Efficiency atau Value Added Capital Employed (VACA), Human Capital Efficiency atau Value Added Human Capital (VAHU) dan Structural Capital Efficiency atau Structural Capital Value Added (STVA) yang dimiliki perusahaan.

\section{Return On Assets}

Ukuran kinerja yang umum digunakan adalah kinerja keuangan. Kinerja keuangan perusahaan dapat diukur dari laporan keuangan yang dikeluarkan secara periodik yang mana memberikan suatu gambaran tentang posisi keuangan perusahaan yang diukur dengan rasio-rasio keuangan. Berbagai rasio dapat digunakan, namun dalam penelitian ini menggunakan rasio keuangan yang mencerminkan efisiensi perusahaan terhadap total aktiva yaitu return on assets (ROA).

Mardiyanto (2009:196), mengatakan return on assets (ROA) adalah rasio yang digunakan untuk mengukur kemampuan perusahaan dalam menghasilkan laba yang berasal dari aktivitas investasi sedangkan (Lestari \& Sugiharto, 2007) mengemukakan bahwa return on assets (ROA) adalah rasio yang digunakan untuk mengukur keuntungan bersih yang diperoleh dari penggunaan aktiva. Semakin tinggi 
rasio ini maka semakin baik produktivitas aset dalam memperoleh keuntungan bersih yang selanjutnya akan meningkatkan daya tarik perusahaan kepada investor.

\section{Pengaruh Value Added Capital Employed (VACA) terhadap Return On Assets (ROA)}

Pemanfaatan efisiensi capital employed dapat meningkatkan return on assets sebagai ukuran dari kinerja keuangan perusahaan karena modal yang digunakan merupakan nilai aset yang berkontribusi pada kemampuan perusahaan dalam menghasilkan pendapatan. Nilai capital employed yang semakin tinggi berarti semakin tinnggi pula efisiensi perusahaan dalam menggunakan modal fisiknya sehingga meningkatkan pendapatan maka diharapkan pula perusahaan akan mampu dalam pencapaian kinerja keuangannya (Devi et al., 2017).

Penelitian yang dilakukan (Fauziah, 2019) studi kasus pada Bank Nagari Sumatera Barat, menyatakan bahwa value added capital employed mempunyai pengaruh positif signifikan terhadap return on assets. Hasil yang sama juga terdapat pada penelitian (Naufallita \& Hendratmi, 2019) yang melakukan penelitian pada 24 Bank Pembiayaan Rakyat Syariah serta (Agusta \& Radianto, 2019) pada perusahaan farmasi yang terdaftar di Bursa Efek Indonesia menunjukkan bahwa capital employed efficiency atau biasa disebut value added capital employed (VACA) berpengaruh positif signifikan terhadap return on assets (ROA). Berdasarkan uraian tersebut, maka hipotesis yang dapat dirumuskan adalah:

H1: Terdapat pengaruh positif signifikan antara Value Added Capital Employed (VACA) terhadap Return On Assets (ROA).

\section{Pengaruh Value added Human Capital (VAHU) terhadap Return On Assets (ROA)}

Value Added Human Capital mengindikasi kemampuan tenaga kerja untuk menghasilkan nilai bagi perusahaan dari dana yang dikeluarkan untuk tenaga kerja tersebut. Human capital di peroleh jika gaji dan tunjangan yang lebih rendah dapat menghasilkan penjualan yang meningkat atau dengan gaji dan tunjangan yang lebih besar diikuti pula dengan penjualan yang semakin meningkat lagi. Gaji dan tunjangan yang lebih besar kepada karyawan diharapkan dapat memotivasi karyawan untuk meningkatkan produktivitas dalam proses produksi (Rahmah, 2018).

Penelitian yang dilakukan oleh (Thakur, 2017) pada bank sektor publik dan swasta di Indian Stock Exchanges mengemukakan hasil bahwa value added human capital atau yang kerap disebut human apital efficiency berpengaruh postif signifikan terhadap Return On Assets. (Pratama \& Achmad, 2015) juga melakukan penelitian pada perusahaan perbankan yang terdaftar di Bursa Efek Indonesia tahun 2009 hingga 2013, (Amalia \& Rokhyadi, 2020) pada perusahaan subsektor advertising, printing dan media menunjukkan bahwa value added human capital berpengaruh positif signifikan terhadap return on assets, lalu ada penelitian dari (Siti Sendari, Dewi Isbanah, 2018) pada perusahaan sektor industri barang konsumen yang menyatakan bahwa value added human capital berpengaruh positif terhadap return on assets. Berdasarkan uraian tersebut, maka hipotesis yang dapat dirumuskan adalah:

H2: Terdapat pengaruh positif signifikan antara Value Added Human Capital (VAHU) terhadap Return On Assets (ROA)

\section{Pengaruh Structural Capital Value Added (STVA) terhadap Return On Assets (ROA)}

Structural capital timbul dari proses dan nilai organisasi yang mencerminkan fokus internal dan eksternal perusahaan yang disertai dengan pengembangan dan pembaharuan nilai untuk masa mendatang. Structural capital memberi kemampuan pada perusahaan dalam memenuhi proses rutinitas perusahaan dan strukturnya yang mendukung usaha karyawan untuk menghasilkan kinerja intelektual yang optimal (Devi et al., 2017).

Penelitian yang dilakukan (Akmil et al., 2019) pada sub sektor perdagangan barang produksi yang terdaftar di Bursa Efek Indonesia kemudian penelitian (Devi et al., 2017) pada perusahaan elektronik, otomotif dan komponen yang terdaftar di Indonesia Stock Exchange menyatakan bahwa structural capital value added berpengaruh positif terhadap return on assets. Berdasarkan uraian tersebut, maka hipotesis yang dapat dirumuskan adalah:

H3: Terdapat pengaruh positif signifikan antara Structural Capital Value Added (STVA) terhadap Return On Assets (ROA) 


\section{METODE PENELITIAN}

Penelitian ini dilaksanakan pada perusahaan subsektor otomotif dan komponen yang terdaftar di Bursa Efek Indonesia (BEI) periode 2015 - 2019. Obyek penelitian atau variabel penelitian yaitu Value Added Capital Employed (VACA), Value Added Human Capital (VAHU), Structural Capital Value Added (STVA) dan ROA (Return On Asset). Populasi dalam penelitian ini adalah seluruh perusahaan sub sektor otomotif dan komponen yang terdaftar di Bursa Efek Indonesia (BEI) sebanyak 13 perusahaan dengan sampel yaitu 5 perusahaan. Teknik analisis yang dipergunakan adalah analisis regresi linear berganda.

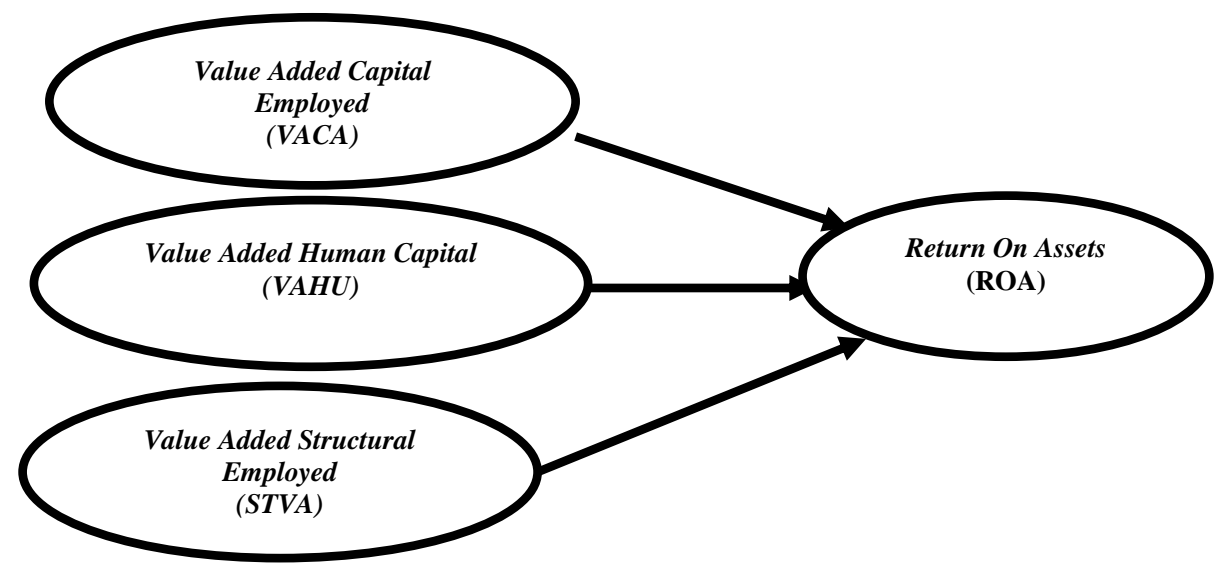

\section{Gambar 1.1 Model Penelitian}

\section{HASIL PENELITIAN DAN PEMBAHASAN}

1. Uji Asumsi Klasik

Hasil pengujian normalitas dengan uji statistik non-parametrik kolmogorov-smirnov (K-S) menunjukkan nilai Asymp. Sig. (2-tailed) adalah 0, 200. Nilai 2-tailed yang menghasilkan lebih besar dari 0,05 maka mengindikasikan data sampel berdistribusi normal pada perusahaan sub sektor otomotif dan komponen. Hasil Uji Multikolinieritas menunjukkan bahwa semua variabel bebas mempunyai nilai tolerance di atas 0,1 dan nilai VIF di bawah 10 sehingga dapat disimpulkan bahwa model regresi pada penelitian ini tidak terjadi multikolinieritas. Berdasarkan hasil uji run test nilai Asymp. Sig. (2-tailed) sebesar 0,223 lebih besar dari 0,05 maka dapat disimpulkan bahwa tidak terjadi gejala autokorelasi. Uji heteroskedastisitas dilakukan menggunakan uji glejser dengan hasil nilai Sig. semua variabel independen lebih besar dari 0,05 maka dapat disimpulkan bahwa tidak terjadi heteroskedastisitas.

2. Berdasarkan tabel 1 diketahui persamaan linier regresi berganda sebagai berikut:

Tabel 1. Hasil Analisis Regresi Linear Berganda

\section{Coefficients $^{\mathrm{a}}$}

\begin{tabular}{|c|c|c|c|c|c|}
\hline \multirow[b]{2}{*}{ Model } & \multicolumn{2}{|c|}{$\begin{array}{l}\text { Unstandardized } \\
\text { Coefficients }\end{array}$} & \multirow{2}{*}{$\begin{array}{c}\begin{array}{c}\text { Standardized } \\
\text { Coefficients }\end{array} \\
\text { Beta }\end{array}$} & \multirow[b]{2}{*}{$\mathrm{t}$} & \multirow[b]{2}{*}{ Sig. } \\
\hline & $\mathrm{B}$ & Std. Error & & & \\
\hline $1 \quad$ (Constant) & $-1,363$ & 2,196 & &,- 621 &, 542 \\
\hline VACA &, 226 &, 048 & ,709 & 4,676 &, 000 \\
\hline VAHU &,- 003 &, 009 &,- 161 &,- 286 &, 777 \\
\hline STVA & 1,316 & 2,492 & ,297 &, 528 & ,603 \\
\hline
\end{tabular}


a. Dependent Variable: ROA

Sumber: Hasil analisis data (2020)

$$
\begin{aligned}
& Y=\alpha+b_{1} X_{1}+b_{2} X_{2}+b_{3} X_{3} \\
& Y=-1,363+0,226 X 1-0,003 X 2+1,316 X 3
\end{aligned}
$$

3. Hasil pengujian pengaruh value added capital employed (VACA) terhadap return on assets (ROA) diperoleh koefisien regresi variabel value added capital employed (VACA) bernilai positif 0,226 dengan nilai signifikansi sebesar 0,000 lebih kecil dari 0,05 (Sig. < 0,05) artinya value added capital employed (VACA) mempunyai pengaruh positif dan signifikan terhadap return on assets (ROA). Hasil uji t pada hipotesis $\mathrm{H} 1$ diterima yang menyatakan bahwa terdapat pengaruh positif signifikan antara value added capital employed terhadap return on assets (ROA).

4. Hasil pengujian pengaruh value added human capital (VAHU) terhadap return on assets (ROA), diperoleh koefisien regresi variabel value added human capital (VAHU) bernilai negatif - 0,003 dengan nilai signifikansi sebesar 0,777 lebih besar dari 0,05 (Sig. > 0,05) artinya value added human capital berpengaruh negatif dan tidak signifikan terhadap return on assets (ROA). Hasil uji t pada hipotesis $\mathrm{H} 2$ ditolak yang menyatakan bahwa terdapat pengaruh positif signifikan antara value added human capital terhadap return on assets (ROA).

5. Hasil pengujian pengaruh structural capital value added (STVA) terhadap return on assets (ROA) diperoleh koefisien regresi bernilai positif 1,316 dengan nilai signifikansi sebesar 0,603 lebih besar dari 0,05 (Sig. > 0,05) artinya structural capital value added mempunyai pengaruh positif dan tidak signifikan terhadap return on assets (ROA). Hasil uji t pada hipotesis $\mathrm{H} 3$ ditolak yang menyatakan bahwa terdapat pengaruh positif signifikan antara structural capital value added terhadap return on assets (ROA).

\section{Pembahasan}

1) Value Added Capital Employed (VACA) Pengaruhnya Terhadap Return On Assets (ROA)

Hipotesis pertama yang menyatakan bahwa terdapat pengaruh postif signifikan antara value added capital employed (VACA) terhadap return on assets (ROA) diterima. Pengujian hipotesis yang telah dilakukan menunjukkan hasil yang sama dimana value added capital employed (VACA) mempunyai pengaruh positif dan signifikan terhadap return on assets (ROA). Hasil penelitian ini sejalan dengan penelitian (Agusta \& Radianto, 2019) dan (Naufallita \& Hendratmi, 2019). Hal ini menunjukkan bahwa pengelolaan modal berupa ekuitas atau modal sendiri dan laba bersih dapat meningkatkan nilai tambah perusahaan yang pada akhirnya mampu meningkatkan kinerja perusahaan yang dilihat dari nilai return on assets (ROA) perusahaan sehingga dapat dikatakan bahwa perusahaan sub sektor otomotif dan komponen dalam penelitian ini telah menggunakan dana yang tersedia secara optimal guna meningkatkan laba perusahaan dan meningkatkan efisiensi penggunaan aset yang dimiliki. Sesuai dengan teori stakeholder, para stakeholder akan berupaya mengendalikan sumber daya yang dimiliki perusahaan untuk meningkatkan kesejahteraannya. Hasil yang berbeda terjadi pada penelitian (Smriti \& Das, 2017) pada perusahaan Farmasi dan Obat-obatan di Bombay Stock Exchange yang menyatakan bahwa value added capital employed (VACA) berkorelasi negatif dan tidak signifikan artinya modal fisik yang dimiliki perusahaan belum mampu untuk menciptakan value added dalam meningkatkan laba perusahaan.

\section{2) Value Added Human Capital (VAHU) Pengaruhnya Terhadap Return On Assets (ROA)}

Hipotesis kedua yang menyatakan bahwa terdapat pengaruh positif signifikan antara value added human capital (VAHU) terhadap return on assets (ROA) ditolak. Pengujian hipotesis yang telah dilakukan menunjukkan hasil yang berbeda dimana value added human capital (VAHU) mempunyai pengaruh negatif dan tidak signifikan terhadap return on assets (ROA). Hasil penelitian ini sejalan dengan penelitian yang dilakukan (Smriti \& Das, 2017), (Devi et al., 2017) 
serta (Fauziah, 2019). Hal ini menandakan bahwa semakin tinggi nilai value added human capital (VAHU) perusahaan tidak mempengaruhi atau tidak menjamin dapat memicu peningkatan kinerja keuangan dalam hal ini return on assets (ROA) perusahaan. Nilai tambah dalam anggaran perusahaan yang telah dikeluarkan untuk beban karyawan (dalam hal ini gaji karyawan) belum mampu meningkatkan kinerja keuangan atau bisa dikatakan perusahaan belum mampu mendayagunakan sumber daya manusia untuk meningkatkan kinerja keuangan. Human Capital berpengaruh negatif tidak signifikan hal ini mengindikasikan pengelolaan karyawan yang tidak efisien atau belum optimal seperti beban pekerjaan yang tidak sesuai dengan gaji yang diterima kemudian kurangnya pemberian pelatihan atau training yang menyebabkan menurunnya produktivitas karyawan dalam menghasilkan laba sehingga akan menurunkan kinerja keuangan perusahaan yang dilihat dari nilai return on asset-nya. Pemberian pelatihan atau training ini bertujuan sebagai proses pengembangan potensi, pengetahuan, skill atau kemampuan karyawan untuk menciptakan nilai tambah dan keunggulan bersaing bagi perusahaan. Hasil yang berbeda terjadi pada penelitian (Thakur, 2017), (Ozkan et al., 2017), (Pratama \& Achmad, 2015), (Endri, 2020), (Siti Sendari, Dewi Isbanah, 2018) serta penelitian dari (Amalia \& Rokhyadi, 2020) menunjukkan human capital efficiency atau biasa disebut value added human capital (VAHU) memiliki pengaruh positif signifikan terhadap return on assets (ROA).

\section{3) Structural Capital Value Added Pengaruhnya Terhadap Return On Assets (ROA)}

Hipotesis ketiga yang menyatakan bahwa terdapat pengaruh positif signifikan antara structural capital value added (STVA) terhadap return on assets (ROA) ditolak. Pengujian hipotesis yang telah dilakukan menunjukkan hasil yang berbeda dimana structural capital value added (STVA) memiliki pengaruh positif namun tidak signifikan terhadap return on assets (ROA). Hasil penelitian ini sejalan dengan (Marbun \& Saragih, 2018), (Fauziah, 2019) serta (Amalia \& Rokhyadi, 2020). Hal ini menandakan bahwa structural capital belum mampu meningkatkan kemampuan menghasilkan laba perusahaan dan juga belum mampu untuk memenuhi proses rutinitas perusahaan dalam menghasilkan kinerja yang optimal. Tanpa diiringi oleh pengelolaan structural capital yang baik seperti pengelolaan sistem, prosedur dan proses rutinitas perusahaan akan menghambat produktivitas karyawan dalam menghasilkan value added. Artinya karyawan yang memiliki tingkat intelektualitas yang tinggi, tetapi jika organisasi atau perusahaan memiliki sistem, prosedur dan proses rutinitas yang buruk maka intellectual capital tidak dapat mencapai kinerja secara optimal dan potensi yang ada tidak dapat dimanfaatkan secara maksimal, untuk itu sangat diperlukan sistem dan prosedur yang baik guna pencapaian kinerja keuangan perusahaan yang tinggi dalam penelitian ini diukur dari besarnya nilai Return On Assets (ROA) yang dicapai perusahaan. (Okenwa Cy, O., Ndubuisi, A. N., \& Chidoziem, 2017), (Devi et al., 2017), (Kazhimy \& Sulasmiyati, 2019) serta penelitian dari (Akmil et al., 2019) menemukan hasil penelitian yang berbeda. Hasilnya menunjukkan bahwa structural capital efficiency atau disebut dengan structural capital value added (STVA) memiliki pengaruh positif dan signifikan terhadap return on assets (ROA).

\section{SIMPULAN}

Berdasarkan hasil penelitian maka dapat disimpulkan value added capital employed (VACA) berpengaruh positif dan signifikan terhadap return on assets (ROA). Adapun temuan dalam penelitian ini, value added human capital (VAHU) mempunyai pengaruh negatif namun tidak signifikan terhadap return on assets (ROA), structural capital value added (STVA) memiliki pengaruh positif namun tidak signifikan terhadap return on assets (ROA).

Implikasi penelitian ini, pihak manajemen perusahaan sub sektor otomotif dan komponen diharapkan dapat mengelola sumber daya dan pengetahuan karyawan untuk menghasilkan kinerja yang baik bagi perkembangan perusahaan serta bagi investor dan calon investor agar lebih memperhatikan intellectual capital perusahaan sebagai pertimbangan dalam melakukan investasi.

Keterbatasan penelitian ini hanya mengggunakan Return on Assets sebagai variabel kinerja keuangan. Penelitian selanjutnya diharapkan mempertimbangkan kinerja keuangan lainnya seperti market book to value dan earning per share. 


\section{DAFTAR PUSTAKA}

Agusta, C., \& Radianto, E. D. (2019). Intellectual Capital Terhadap Kinerja Perusahaan Farmasi Yang Terdaftar Di Bursa Efek Indonesia ( Bei ) Periode 2009-2017. Media Akuntansi Dan Perpajakan Indonesia, 1(1), 12-24. https://journal.uc.ac.id/index.php/mapi/article/view/1399

Akmil, P. S., Husaini, A., \& Nurlaily, F. (2019). Pengaruh Intellectual Capital Terhadap Kinerja Keuangan ( Studi Pada Perusahaan Sub Sektor Perdagangan Besar Barang Produksi Yang Terdaftar Di Bursa Efek Indonesia Periode 2016-2018 ). Jurnal Administrasi Bisnis, 72(2), 196-204. http://administrasibisnis.studentjournal.ub.ac.id/index.php/jab/article/view/2882

Amalia, L., \& Rokhyadi, A. (2020). Pengaruh Intellectual Capital terhadap Kinerja Keuangan Subsektor Advertising, Printing dan Media. Jurnal Ilmiah Mahasiswa Ekonomi Manajemen, 5(1), 187-200. http://jim.unsyiah.ac.id/EKM/article/view/14365

Devi, B. E., Khairunnisa, \& Budiono, E. (2017). The Influence of Intellectual Capital on the Company Financial Performance (Case Study on Company of Electronic, Automotive and Components Listed in Indonesian Stock Exchange (IDX) on Period 2011-2015). Jurnal Akuntansi, 3(2), 15-26. https://e-jurnal.lppmunsera.org/index.php/Akuntansi/article/view/214

Endri, E. (2020). Impact of Intellectual Capital and Efficiency to the Profitability of Islamic Banking. SSRN Electronic Journal, 7(7), 230-237. https://doi.org/10.2139/ssrn.3649052

Fajariyah, Fitri. 2012. Analisis Pengaruh Implementasi Knowledge Creation, Human Capital, Customer Capital, Dan Structural Capital Terhadap Business Performance (Studi Kasus Pada PT Bank Pembangunan Daerah Jawa Tengah). Skripsi pada Fakultas Ekonomika Dan Bisnis Universitas Diponegoro Semarang.

Fauziah, R. \& D. M. K. (2019). Pengaruh Modal Intelektual Terhadap Kinerja Keuangan di Bank Nagari Sumatera Barat. Academic Conference of Accounting, 1, 62-75. http://ocs.akbpstie.ac.id/index.php/ACAR/ACA1/paper/view/11

Kazhimy, A. F., \& Sulasmiyati, S. (2019). Pengaruh Intellectual Capital terhadap Profitabilitas Perusahaan (Studi pada Sektor Properti dan Real Estate yang Terdaftar di Bursa Efek Indonesia Periode 2015-2017). Jurnal Administrasi Bisnis (JAB), 72(2), 30-39. http://administrasibisnis.studentjournal.ub.ac.id/index.php/jab/article/download/2863/3250

Kompas.com. 2017. Penguatan Industri Komponen Lokal, Kunci Daya Saing Otomotif Nasional. Diakses dari website https://biz.kompas.com/read/2017/10/04/111112228/penguatanindustri\%20komponen-lokal-kuncidaya-saing-otomotif-nasional. Diunduh 03 Desember 2020.

Lestari \& Sugiharto, M. T. (2007). Kinerja Bank Devisa Dan Bank Non Devisa Dan Faktor-Faktor Yang Mempengaruhinya. Proceeding PESAT (Psikologi, Ekonomi, Sastra, Arsitek \& Sipil)., 2(21-22 Agustus). https://docplayer.info/54213852-Lestari-ika-lestari-dan-sugiharto-toto-2007-kinerja-bankdevisa-dan-non-devisa-dan-faktor-faktor-yang-mempengaruhinya-proceeding-pesat.html

Marbun, G., \& Saragih, A. E. (2018). Pengaruh Intellectual capital Terhadap Kinerja Perusahaan Pada Perusahaan Perbankan Yang Terdaftar di BEl. Encyclopedia of Knowledge Management, 4(1), 39-60. http://ejournal.ust.ac.id/index.php/JRAK/article/view/452

Mardiyanto, Handoyo. 2009. Intisari Manajemen Keuangan. Jakarta: PT Grasindo.

Naufallita, Q., \& Hendratmi, A. (2019). the Influence of Intellectual Capital on Return on Assets and Return on Equity Sharia Rural Bank 2015 - 2017 Period. Jurnal Ekonomi Dan Bisnis Islam (Journal of Islamic Economics and Business), 5(2), 124. https://doi.org/10.20473/jebis.v5i2.11787

Okenwa Cy, O., Ndubuisi, A. N., \& Chidoziem, A. M.-F. (2017). Effect of Intellectual Capital on Financial Performance of Banks in Nigeria. Journal of Global Accounting., 5(1), 28-57.

Ozkan, N., Cakan, S., \& Kayacan, M. (2017). Intellectual capital and financial performance: A study of the Turkish Banking Sector. Borsa Istanbul Review, 17(3), 190-198. https://doi.org/10.1016/j.bir.2016.03.001

Pratama, Y. H., \& Achmad, T. (2015). PENGARUH INTELLECTUAL CAPITAL TERHADAP KINERJA PERUSAHAAN DENGAN COMPETITIVE ADVANTAGE SEBAGAI VARIABEL INTERVENING (Studi Pada Perusahaan Perbankan yang Terdaftar di BEI 2009-2013). Diponegoro Journal of Accounting, 4(2), 963-974. https://ejournal3.undip.ac.id/index.php/accounting/article/view/16805

Rahmah, A. N. 2018. Pengaruh Intellectual Capital Terhadap Kinerja Keuangan Bank Syariah.Skripsi pada Fakultas Ekonomi Dan Bisnis Islam. Universitas Islam Negeri Ar-Raniry Banda Aceh.

Siti Sendari, Dewi Isbanah, Y. (2018). Pengaruh Intellectual Capital Terhadap Kinerja Keuangan Sektor Industri Barang Konsumen Di Bei 2014-2016. Jurnal IImu Manajemen (JIM), 6(3), 173-182. https://jurnalmahasiswa.unesa.ac.id/index.php/jim/article/view/23897/21839

Smriti, N., \& Das, N. (2017). Impact Of Intellectual Capital On Bussines Performance: Evidence From 
Indian Pharmaceutical Sector. Polish Journal of Management Studies, 15(1), 232-243. https://doi.org/10.17512/pjms.2017.15.1.22

Thakur, V. S. (2017). Intellectual Capital: Its Effect on Financial Performance of Indian Private Sector Banks. International Journal of Advanced Scientific Research and Management, 3(2), 100-106. https://www.rroij.com/open-access/intellectual-capital-its-effect-on-financial-performance-ofindianpublic-and-private-sector-banks-.pdf

Ulum, I. 2017. Intellectual Capital: Model Pengukuran, Framework Pengungkapan \& Kinerja Organisasi. Malang, Indonesia: UMMPress. 